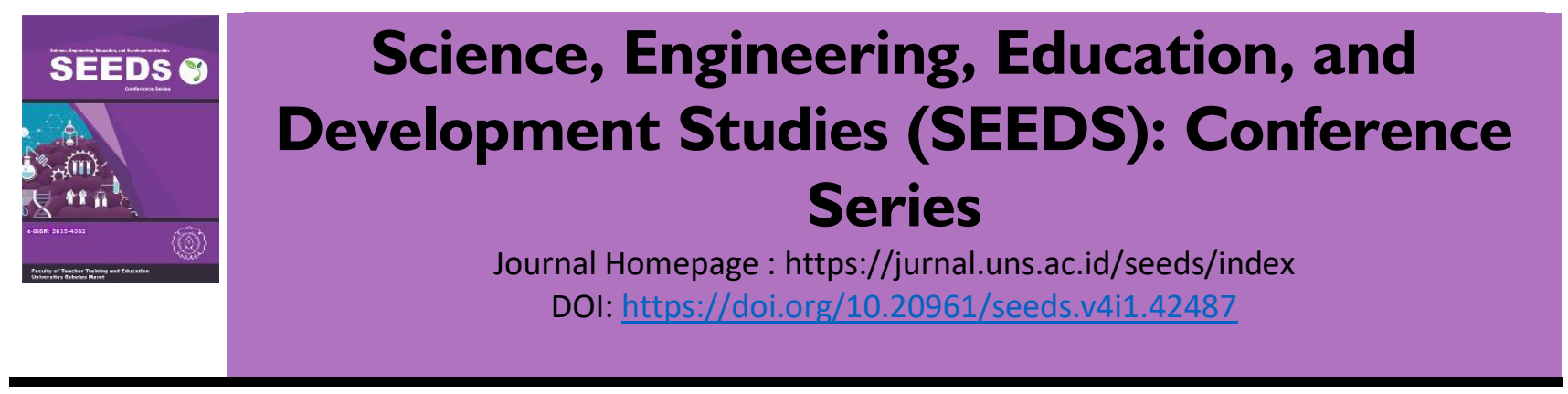

\title{
ANALYSIS OF PRINCIPAL'S MOTIVATION AND LEADERSHIP TECHNOLOGY PATHWAY THROUGH MEDIATOR LEARNING STRATEGIES WITH GENDER MODERATORS IN MAYA SEESAW CLASSES \\ ST Nurjaningsih \\ Doctoral Program in Educational Science, Sebelas maret University
}

nurjaningsih@student.ac.id, bdhwi@yahoo.co.id, sunardi.ipuns@gmail.com, karmin.abdulkarim@gmail.com

\section{Article Info :}

Available online $24 / 11 / 2021$

\section{Keywords:}

motivation

learning strategies

technology ledearship

mediators

moderator

\begin{abstract}
The purpose of this study is to explore motivations mediated by the integrated learning strategies of Communication Information Technology (ICT) for improving the technology leadership of school principals by moderating the gender variable in the virtual class seesaw during the training of strengthening the competency of the Principal of the Kendal Vocational School in 2019. This research was conducted using quantitative approach using cross-sectional design. Path analysis is used to determine the effect of motivation on the principal's leadership through learning strategies with gender moderator factors. Vocational school principals who participated in this study as many as 30 participants who participated in the training of strengthening the competency of vocational school principals. At the end of the training, the principals answered the motivation questionnaire, learning strategies and principals' leadership. The findings from the path analysis show that the learning strategy variable is a significant mediator in the relationship between the independent motivation variable and the dependent variable in the improvement of the principal's technological leadership where the sex factor as a moderator is equally strong. It can be concluded that motivation by the use of learning strategies in the principal's training curriculum that integrates ICT through seesaw virtual classes can improve the technology leadership of SMK headmasters for all genders indirectly. The findings from the path analysis show that the learning strategy variable is a significant mediator in the relationship between the independent motivation variable and the dependent variable in the improvement of the principal's technological leadership where the sex factor as a moderator is equally strong. It can be concluded that motivation by the use of learning strategies in the principal's training curriculum that integrates ICT through seesaw virtual classes can improve the technology leadership of SMK headmasters for all genders indirectly.
\end{abstract}


The findings from the path analysis show that the learning strategy variable is a significant mediator in the relationship between the independent motivation variable and the dependent variable in the improvement of the principal's technological leadership where the sex factor as a moderator is equally strong. It can be concluded that motivation by the use of learning strategies in the principal's training curriculum that integrates ICT through seesaw virtual classes can improve the technology leadership of SMK headmasters for all genders indirectly.

\section{INTRODUCTION}

Rapid technological progress, especially in the Industrial Revolution 4.0 clearly affected every aspect of our lives including leadership and education throughout the world (Schwab \& Davis, 2018). Advanced technology in the industrial era 4.0 such as Artificial Intelligence (AI) and the internet changed the role of school leadership, teaching approaches, and school innovation.

School leaders have a responsibility to encourage and support teachers to integrate technology in learning and to teach especially when internates develop quickly into classrooms in ways never imagined. With smart whiteboards and alternative interactive digital media that are widely used during interactive learning in classrooms, school leaders must keep abreast of new technological developments.

Technology leaders are required to utilize technology to transform, influence learning, and create a shared vision of how technology can meet the needs of all students. Therefore it is very important for school leaders to imagine and facilitate the use of technology in this digital world everywhere for students who are now digital natives. However, according to a report by the World Economic Forum (2019), poor leadership can be the biggest obstacle to the success of the 4.0 industrial revolution strategy.

While in Indonesia and other countries, in general the preparation program for school principals does not make education technology compulsory in the school principal preparation program. This is confirmed by the results of the study of Schrum et al (2011) reporting that as many as $92 \%$ of leader preparation courses do not involve technology. Ideally, school leadership preparation training should include technology to produce future school principals who can lead teachers and students, because learning experiences are virtual and ubiquitous (Aldowah et al., 2017; Esplin, 2017). Technology integration by leaders and teachers is influenced by inadequate training, incapacity in ICT, and limited access to ICT (Abdullah et al, 2015).

The innovative learning strategy developed in the 21 st century is a framework for creating challenging learning opportunities that promote thinking, understanding, and learning performance. This happens when using online multi-channel information, collaborative technology tools with great curricular potential and innovative teaching and learning strategies that break traditional curriculum boundaries.

Training for strengthening the competency of school principals in accordance with Pemerndikbud No 6 of 2018 requires school principals not an additional task so that as a manager, learning leader and entrepreneurial developer it is possible to integrate training methods in the form of discussion, assignment and evaluation of learning to apply learning technology applications in the form of virtual seesaw classes. This is to create challenging learning opportunities that promote thinking, understanding, and learning performance. This happens when using online multi-channel information, collaborative technology tools with great curricular potential and innovative teaching and learning strategies.

In addition, internal and external motivational components must be integrated in the curriculum, to help principals face challenges, interactions and experiences, such as cooperative studies, supportive social networks and entrepreneurship (Nigh et al., 2015).

The purpose of this study was to analyze the effects of motivation to improve the technology leadership of school principals by mediating innovative learning strategies in the seesaw class with the sex moderators of vocational school principals training participants in strengthening the competency of principals. 


\section{LITERATURE REVIEW}

\section{Motivation}

The origin of the term 'motivation' is the word 'motion'. In the past, the definition of motivation mainly refers to the impulses and instincts that cause a person to act. Over the years, differentiation has developed between intrinsic and extrinsic motivation. This difference becomes very central in any discussion of motivation. Deci and Ryan(1985), defines intrinsic motivation as interest in actual activities. Intrinsic motivational behavior is pleasure and interest, and has no external rewards except that enjoyment (Ryan and Deci, 2000). This behavior also involves constant difficulty with difficulty and willingness to acquire the required skills. In contrast, extrinsic motivation refers to participation in an activity based on external values and demands (Deci et al.1991). External regulators' behavior is controlled by demands and social rewards. Research found that intrinsic motivation is related to learning achievement and positive psychological aspects, more than extrinsic motivation (Gottfried et al.2007).

A theory that explains the processes that influence learners to survive with their studies is the theory of self-determination, which is based on a humanistic approach (Ryan and Deci.,2000). This theory assumes that every person has three basic psychological needs: the need for connection and connection, the need for self-efficacy, and the need for autonomy. Meeting these basic needs is very important, because it enables optimal functioning, personal growth, and social development. Studies reveal that environmental conditions that meet three basic psychological needs contribute to the development of intrinsic motivation (Katz et al.,2008), while environmental variables can promote or inhibit this motivation. Meeting these needs leads to the formation of a person by self-determination, while denying or preventing the fulfillment of these needs damages the quality of motivation and sometimes reduces his strength. Therefore, the motivation that drives among students is important in the education process (Assor et al, .2014). However, motivation alone is not enough to achieve positive academic achievement.

Pintrich (2000),has developed a social cognitive model that shows self-regulated stages and areas of learning, which reflect the process of goal setting, monitoring, control and supervision. The basic assumption is that each student is able to teach, learn skills, positions, and beliefs, with the help of most of the other students in the group (Pintrich.,2004). In this learning process, motivational orientation and learning strategies used to achieve different goals, academic and social, are important (Pintrich,2003). In this model, student motivation is directly related to the ability of self-direction in learning activities. Motivation is assumed to be dynamic and contextual. Learning strategies can be learned and monitored.

Pintrich(2000) has divided the fields

Motivational orientation into three components:

1. Expectation component: beliefs about learning mastery abilities and self-efficacy

2. Components of assignment grades: beliefs about course grades, intrinsic orientation, and extrinsic orientation

3. Emotional component: feelings of duty

\section{Learning Strategies}

The term learning strategy has different definitions, most of which seem to have shared content. Here are a number of definitions:

1. The process of thinking and learning behavior skills, which are operated by learners to improve the efficiency of their learning and the mastery of the knowledge they learn (Weinstein et al.1988);

2. The sequence or ensemble of instructions and guidelines given to students before, during, and after doing assignments (Riding and Rayner,1998);

3. All thoughts, behaviors, beliefs, or feelings that help gain understanding and transfer of new knowledge and skills (Weinstein et al.2000).

Learners operate the process of meta-cognitive thinking while implementing learning strategies. The learner not only follows the teacher's instructions, he also directs their thoughts and control, he is aware of his ability to analyze events as they appear, and is aware of the decision making process. With the help of this instruction, students can monitor their thoughts on one side, and solve new and unexpected problems while doing assignments, on the other (Riding and Rayner,1998). 
Self-regulated learning theory includes learning strategies, which are processes on the basis of doing thinking tasks. Pintrich (2000) divides the learning strategy area into three components:

1. Meta-cognitive strategies: assume that students have awareness and knowledge about cognition, and include planning, monitoring, and regulation.

2. Cognitive strategies: actual strategies for performing tasks, which include recap, expansion, organization and pooling of knowledge, and critical thinking.

3. Resource management strategies: strategies that allow students to shape the learning environment according to their needs, such as: the use of time and learning environment, peer learning, and seeking help.

Students with self-management skills can create opportunities to work in teams, learn from mistakes, develop awareness and sensitivity to their own emotional situations and those of their peers, and evaluate their learning and achievement according to the scale of values set in the group. According to the literature, self-regulation in learning contributes to learning and academic achievement, but it is still unclear what level of development each component has about the age of the student, the optimal stage at which students must develop these strategies, the guidance that must be given to them, and whether the component components reflect the arrangements yourself in learning in innovative learning environments (Wolters,2010).

\section{Technology Leadership}

Third, leadership is an important aspect of school reform (Chang, 2012) second only to quality teaching (Leithwood \& Jantzi, 2006; Anderson, \& Dexter, 2000). They argue that leadership has been underestimated in relation to improvements in student learning (Robbin \& Judge, 2013). Leadership was identified as an important factor in embracing new pedagogy in an environment of collaborative knowledge development (Chang, 2012). However, there are gaps in the literature that focus on how school leaders foster technologyrich scientists (Leong et., Al, 2016). For the purpose of this study, the focus is on the leadership of the principal; based on a distributed leadership perspective that some leaders and leadership activities coexist (Leithwood \& Jantzi,

In Alberta, there is concern for improvements in technological leadership (Alberta Education, 2013b) but leadership dimensions or competencies for principals, such as Principal Quality Practices Guidelines (Alberta Education, 2009) or ISTE standards (2009) for administrators, rarely highlight important conditions which supports technology leadership with a growth orientation.

ISTE (2014) includes a set of instructional roles for technology leaders in schools whose visionary leadership, digital age learning culture, excellence in professional practice, systemic improvement, and digital citizenship. These standards are the skills and knowledge needed by administrators and school leaders to successfully integrate technology in schools (ISTE, 2014).

The operational definition for each construct is as follows: Visionary leadership means educational administrators inspire and lead the development and implementation of technology integration (ISTE, 2014). Digital age learning culture, education administrators maintain a digital age learning culture that provides attractive education for all students (ISTE, 2014). Excellence in professional practice, education administrators promote professional learning and innovation that empowers educators to enhance student learning through technology and digital resources (ISTE, 2014). Systemic improvement means educational administrators provide leadership and management of the digital age to continuously improve organizations through the effective use of information and technology resources (ISTE, 2014).

The impact of gender on leadership styles has been debated over the past decade (Yukl, 2013). Expectations of roles that influence leader behavior can make it difficult to differentiate gender differences. Over the past decade, gender has been an important predictor of technological leadership (Leong et al., 2016). In addition, previous research on gender related to leadership behavior is inconsistent (Eagly, 1995). A study by Alkrdem (2014) showed that the technological leadership behaviors of "headteachers" did not differ with respect to their gender in Saudi Arabia. However, according to Banoglu (2011), female technology leaders are more effective than male technology leaders in Turkey. In addition to these findings, Waxman et al., (2013) states that gender influences how leaders understand the function of technology in their schools in the 
United States. In Malaysia, previous research showed that the sex of school leaders did not have a significant influence on technology leadership (Hamzah et al., 2010).

Alkrdem (2014) studied the behavior of school leaders in 135 secondary schools in Saudi Arabia and found that school leaders showed high-tech leadership. Leong et al. (2016) found that the practice of technological leadership correlates with teacher ICT competencies and is supported by many leadership theories (Bass \& Bass, 2008; Bush. 2011; Leithwood \& Jantzi, 2006; Northouse, 2013; Robbin \& Judge, 2013; Yukl, 2013) .

This finding is in line with Papa (2011) who postulates that only school technology leaders have the power to make instructional decisions related to technology and technology program implementation. In addition, individual characteristics such as age, gender, and experience theorize to moderate the relationship between the dimensions of technology leadership and technology integration. Based on previous research, this study examines the contribution of motivation to improve the competency of principals' technology leadership through learning strategies that are influenced by gender factors. The hypothesis proposed in this study is:

H1: There is a significant positive relationship between motivation (MV) and learning strategies (SP)

$\mathrm{H} 2$ : There is a significant positive relationship between learning strategies (SP) and technology leadership for school principals (KT)

H3: There is a positive relationship between motivation and technology leadership of principals mediated by learning strategy factors

$\mathrm{H} 4$ : Gender is a moderating factor in motivation through learning strategies to improve the technology leadership of the principal

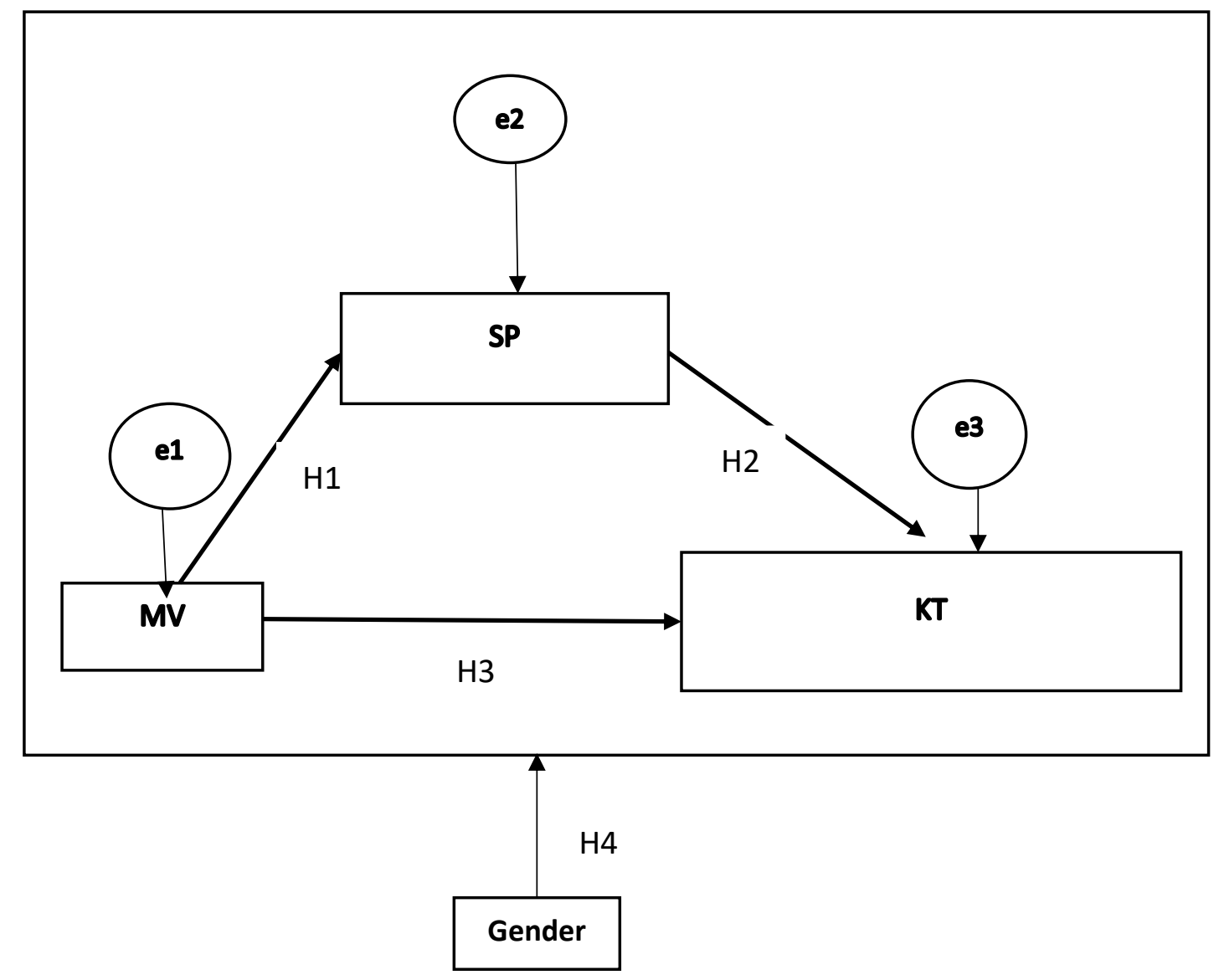

Fig 1. Hypothetical Research Model 


\section{RESEARCH METHOD}

\section{Participant}

It consists of 30 SMK Principals from Kendal Regency who are currently undergoing training in strengthening the competency of school principals to obtain the headmaster's professional certification in 2019 from 7 to 14 May 2019 organized by LPPKS in collaboration with the Kendal District Education Office. There are 12 female principals and 18 male men. The principal's competency strengthening training program includes 71 hours of learning covering the main material of leadership, managerial and entrepreneurship development and follow-up. Previous learning methods in the form of discussion, assignments, presentations and face to face full. In this research, blended learning is tried for topics that allow so that assignments, materials and portfolios are tested in electronic form provided in the seesaw class.

\section{Research tools}

The hypothesis is tested through a questionnaire of motivation, learning strategies and technology leadership of the principal. The motivation questionnaire and learning strategy were adopted from instruments developed by Duncan and Mc Keachie (2005). The questionnaire for technological leadership was developed based on concepts from ISTE (2014) and technology experience surveys (Billheimar, 2007).

The motivational orientation field consists of 24 items including five indicators: intrinsic orientation, extrinsic orientation, beliefs about the value of the course, beliefs about mastery over learning, and selfefficacy for learning and performance. The learning strategy area consists of 43 items in eight indicators: practice, elaboration, organizing, critical thinking, metacognitive self-regulation, time and environmental management studies, peer learning, and seeking help.

The dimensions of technological leadership include 21 items with six five indicators building a culture of learning in the digital age, digital pride, excellence in professional practice, visionary leadership, professional development and systemic improvement.

The instruments are designed according to a 5-level Likert scale, ranging from absolutely not true about me (1) to very true about me (5). For each respondent the motivational instruments, learning strategies, and indicators of technological leadership achievement are calculated according to the average contents for the questionnaire indicator items.

\section{Method of analysis}

This research is classified as quantitative using a cross-sectional design. The analysis used is path analysis using SPSS 22 software. Validitytested by comparing the scores on Corrected Item-Total Correlation which is the correlation between item scores and total item scores, compared to the value of the calculation rule is if the calculated $r$ value is greater than the rtable value. At the significance level $\alpha=0.05$, the product moment value obtained value $=0.374$, then the Correlated Item Total Correlation value $>0.374$ is obtained so that it is declared valid for all items. While the reliability of the data was measured using the Cronbach alpha method with a score of 0.815 so it was stated that the instrument was quite reliable.

\section{RESULT}

The results of the study after being processed obtained a picture of the correlation between the variables indicated by the data as follows: 
Table 1. Pearson correlation coefficient matrix between motivation, learning strategies and technology leadership $(\mathbf{N}=30)$.

\begin{tabular}{lcccc}
\hline & Motivation & $\begin{array}{c}\text { Learning } \\
\text { strategy }\end{array}$ & $\mathbf{M}$ & $\begin{array}{c}\text { Elementary } \\
\text { school }\end{array}$ \\
\hline Motivation & - & & 3.73 & .73 \\
Learning & $.669(* *)$ & 3.06 & 0.68 \\
strategy & & & \\
$\begin{array}{l}\text { Technological } \\
\text { leadership }\end{array}$ & $.602(* *)$ & $.652(* *)$ & 3.53 & 0.58 \\
$* * \mathrm{p}<0.05$ & & & &
\end{tabular}

From table 1 shows a significant positive strong correlation between motivation, learning strategies, and technology leadership. The higher the motivation of students, the higher the learning strategy is implemented and the higher the technological leadership.

Table 2 Standard Summary Model R Square Model Path Analysis Model 1

\begin{tabular}{ccccc}
\hline & & & Adjusted R & Std. Error of the \\
Model & $\mathrm{R}$ & R Square & Square & Estimate \\
\hline 1 & $.753 \mathrm{a}$ & .567 & .552 & 2.70556 \\
\hline
\end{tabular}

a. Predictors: (Constant), MV

Table 3. Coefficientsa

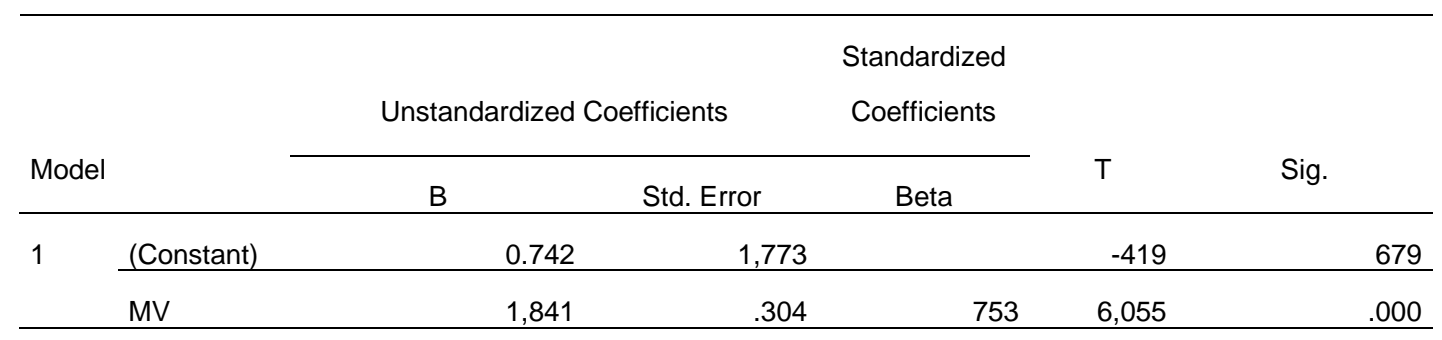

a. Dependent Variable: Learning Strategies

The significance value of 0,000 at $\mathrm{p}<0.05$ means that the model can be used to test the effect of motivation on learning strategies with the following equation form $\mathrm{Y}=0.742+1.84$ Motivation $+\varepsilon$ thus $\mathrm{H} 1$ is proven. For $\mathrm{H} 2, \mathrm{H} 3$ and $\mathrm{H} 4$ are concluded based on further calculations based on model 2 as follows: 
Table 4. R Square Model Motivational Relations (MV) to Technology Leaders (KT) Mediated by Learning Strategy Variables (SP)

(Model 2)

Summary Model

\begin{tabular}{llcccc}
\hline \multicolumn{5}{c}{ Summary Model } \\
Model & R & R Square & Adjusted R & Std. Error of the \\
& Square & Estimate \\
\hline 2 & $.709 \mathrm{a}$ & .503 & & 669 & 15.90581 \\
\hline
\end{tabular}

a. Predictors: (Constant), MV, SP

Table 5. Results of the Statistical Analysis of the Model Coefficients Path Analysis Model 2

\begin{tabular}{|c|c|c|c|c|c|c|}
\hline \multicolumn{7}{|c|}{ Coefficientsa } \\
\hline \multirow[b]{3}{*}{ Model } & & \multicolumn{5}{|c|}{ Standardized } \\
\hline & & \multicolumn{2}{|c|}{ Unstandardized Coefficients } & \multirow{2}{*}{$\begin{array}{c}\text { Coefficients } \\
\text { Beta }\end{array}$} & \multirow[b]{2}{*}{$\mathrm{T}$} & \multirow[b]{2}{*}{ Sig. } \\
\hline & & $\mathrm{B}$ & Std. Error & & & \\
\hline \multirow[t]{3}{*}{2} & (Constant) & 92,222 & 19,524 & & 4,724 & .000 \\
\hline & MV & .139 & .171 & .313 & .615 & .002 \\
\hline & SP & .31 & .244 & .428 & .140 & .009 \\
\hline
\end{tabular}

a. Dependent Variable: KT

Significance at $\mathrm{p}<0.05$, because it is 0.009 then $\mathrm{H} 0=$ rejected, $\mathrm{H} 1=$ accepted

Based on multivariate regression analysis with SPSS 22 software test obtained standard coefficient $(\beta)$ of motivation on learning strategies $(\beta=0.753, \mathrm{p}<0.05$ ). This means that the higher the motivation of the principal, the higher the person involved in implementing the learning strategy during the technology integrated training activities in the virtual seesaw class. While the standard coefficient of learning strategy variables on technology leadership is $0.428(\beta=0.428, \mathrm{p}<0.05$. This means that learning strategies have a significant positive effect on technological leadership while moderate. While the direct independent effect of motivation on the dependent variable of technological leadership is $0.313(\beta=0.363, p<0.05)$ Means that motivation has a small positive effect on technology leadership The mathematical equation of model 2 is $\mathrm{Y}=92$,

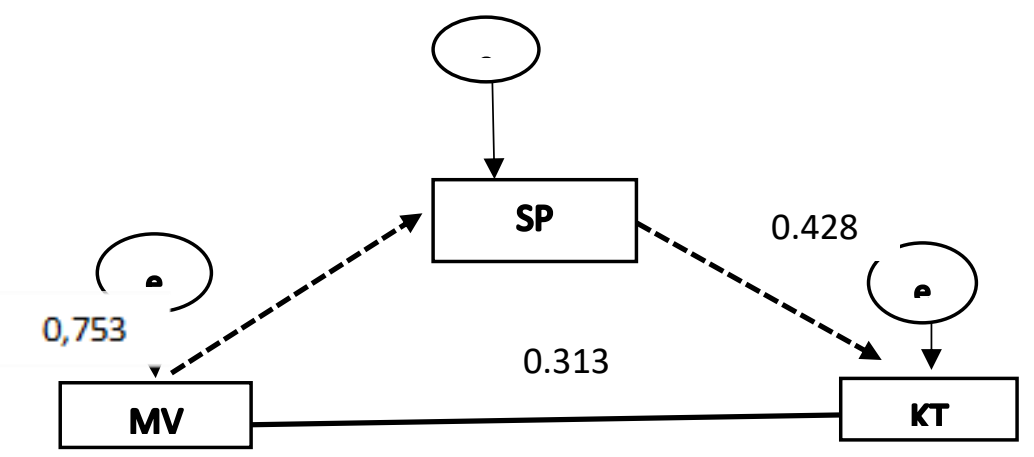

Figure 2. Motivation Path Analysis Model (MV), Learning Strategies (SP) as a mediator towards Technology Leadership (KT) 
Table 6. Path Analysis Model Coefficients

\begin{tabular}{ccccc}
\hline Hypothesis & Relationship & $\boldsymbol{\beta}$ & Significance & Finding \\
\hline H1 & MV x SP & .753 & 0,000 & Supported \\
H2 & SP x KT & 0.428 & 0.002 & Supported \\
H3 & MV x KT & 0.313 & 0.009 & Supported \\
\hline
\end{tabular}

Based on the table above can be explained the influence of total motivation on technology leadership consists of two categories, namely direct and indirect influence through learning strategies. So the magnitude of the indirect effect of $0.753 \times 0.428=0.322$, the indirect effect is greater than the direct effect $(0.313)$. This means that the learning strategy mediator variable significantly influences the motivational effect on technology leadership.

While the results of testing the effects of gender moderation according to the $\mathrm{H} 4$ hypothesis that was formulated showed the effect of the sex moderating variable showed no significant. In accordance with table 4 the significance above $>0.05$ for all correlations thus it can be concluded that gender variables do not affect motivation, learning strategies and their interactions with variables dependent on the technology leadership of the principal

Table 7. Results of the moderator test coefficient analysis

\begin{tabular}{|c|c|c|c|c|c|c|}
\hline \multicolumn{7}{|c|}{ Coefficientsa } \\
\hline \multirow[b]{3}{*}{ Model } & & \multirow{2}{*}{\multicolumn{2}{|c|}{ Unstandardized Coefficients }} & \multirow{3}{*}{$\begin{array}{c}\text { Standardized } \\
\text { Coefficients } \\
\text { Beta } \\
\end{array}$} & \multirow[b]{3}{*}{$t$} & \multirow[b]{3}{*}{ Sig. } \\
\hline & & & & & & \\
\hline & & B & Std. Error & & & \\
\hline \multirow[t]{4}{*}{1} & (Constant) & 74,067 & 42,208 & & 1,755 & .91 \\
\hline & MV & 2,445 & 7,446 & -.264 & -328 & .745 \\
\hline & Gender & 6,336 & 23,676 & -193 & -.268 & .791 \\
\hline & Mv x Gender & 1,637 & 4,143 & .432 & .395 & 696 \\
\hline
\end{tabular}

a. Dependent Variable: KT

\section{DISCUSION AND CONCLUSION}

This study emphasizes the behavioral component of the learning strategy as a mediator between the motivation of the training participants to strengthen the competency of school principals who integrate communication technology in their learning activities to enhance technological leadership. This contradicts the cognitive model, which emphasizes the importance of beliefs and perceptions as mediators of behavior (Martin2008). The research findings show that using various learning strategies directly influences the sense of technological leadership, and moreover, the use of various learning strategies is the main mediator who 
actually expresses the principal's motivation to learn during the training activities. Schrum et.al., (2011) claims that a student with high self-regulation for learning can create opportunities for teamwork, learn from mistakes, develop awareness and sensitivity for his or her emotional situation, and evaluate their learning and achievement according to the scale set on a group scale. In the current program, training participants use a variety of learning strategies during learning and understand the demands of performance that they should. Learning strategies, according to Weinstein et al., (1988), is a cognitive process and learning skills run by students to improve learning efficiency and expertise in the knowledge learned. In the class seesaw various features allow exploration of techniques and thinking skills to be achieved during training.

In addition, cognitive strategies, including recap, expansion, organization and pooling of knowledge, and critical thinking (Pintrich 2000) in use by training participants to promote learning and understand performance. Group learning is based on the strengths and cognitive abilities of each student. For example, when training participants watch videos or read articles in cybersaw classes and have professional insight through them, they share with their peers, explain, demonstrate, and act to promote understanding of the whole group. It seems that the intervention program is focused on providing learning strategies, and according to research findings, it is possible that relevant experience in various learning strategies has helped students to understand and move forward in course work, and thus turn them into skilled students with a sense of achievement who are high in learning during the training. Based on this learning there is motivation to gain knowledge during learning and use knowledge efficiently. This finding may indicate that the use of informed learning strategies, based on motivational orientation, such as intrinsic orientation, beliefs about the value of courses, and self-efficacy, allows creating a deep and broad picture of the learning characteristics and understanding of technological leadership.

Other than that, it was found that the expansion of the model in the learning program during integration in the virtual classroom seesaw, the principle of the game was included. This principle has the potential for learning experiences, and increases motivation and learning strategies among students (KAPP2012). In gamification, students receive virtual prizes for learning and success, such as graphic notes, virtual medals, and animation changes according to success. For example, the use of the barcode scanner application as a gift in accordance with the information behind the code.

Metcalf (2012) also suggested that technology leadership training should be carried out in line with the headmaster preparation program carried out at universities according to ISTE standards. Principals who inspired school vision and effective technology integration and provided continuous professional development were found to be most effective in influencing teachers to integrate technology in the classroom (Kurland et al., 2010).

Because professional development proves to be important and has a high performance index value regarding technological leadership, sustainable professionals are more effective. Through this training, technology must be used to innovate in learning and teaching experiences in the classroom through the teacher as a mediator.

This study also proves that gender is not a moderating factor in the relationship between principal technology leadership and teacher technology integration. The findings of this study are in line with Hamzah et al., (2010) and Alkrdem (2014) that gender does not affect technological leadership. On the other hand, it contradicts the findings of Banoglu (2011) who postulate that women technology leaders are more effective, especially in the construction of visionary leadership. This finding contradicts research conducted by Heafner (2014) which suggests that gender plays an important role in technology integration. The results of this study illustrate the gradual closing of the gender gap between technology leaders because male and female leaders are able to implement the ISTE (2014) standard for technology leaders. Apart from this, The findings of this study prove that gender is also not a moderating factor between professional development and technology 
integration. This study shows that professional development in the field of ICT can be carried out without gender bias for male and female leaders in line with future generations of the millennium.

The results of this study illustrate the gender gap between technology leaders where male and female leaders are able to implement the ISTE standard (2014) as technology leaders. Therefore it is recommended that efforts directed at bridging the gender gap should be carried out actively and continuously by all stakeholders in the policy makers. Since there are not many studies examining gender as a moderating variable between the technology leadership of vocational school principals and motivational factors and learning strategies it is hoped that this research will pioneer more research on gender and other factors such as school location and school climate.

Further research with a larger sample size is recommended or in other training patterns. Because this is quantitative research, it is recommended that further research be carried out using analysis using qualitative data for in-depth studies of the effect of gender on motivation or other independent variables on the relationship between technology leadership and technology integration of principals other than SMK.

\section{REFERENCES}

Abdullah, N., Khalid, H., \& Hamzah, MIM (2015, March 9-10). The practice of technology leadership in ICT integration at national secondary schools in Malaysia [Conference session]. Proceeding of the 3rd Global GSE Summit on Education 2015, Kuala Lumpur, Malaysia.

Aldowah, H., Rehman, SU, Ghazal, S., \& Umar, IN (2017). Internet of Things in higher education: A point on future learning. Journal of Physics, 892 (1), 012017.https: // doi. org / 10.1088 / 1742-6596 / $892 / 1 / 012017$

Alkrdem, M. (2014). Technological leadership behavior of high school head teachers in Asir Region, Saudi Arabia. Journal of International Education Research, 10 (2), 95-100. https://doi.org/10.19030/jier.v10i2.8510

Anderson, RE, \& Dexter, SL (2000). School leadership technology: Incidence and impact (Teaching, Learning, and Computing: 1998 National Survey, Reports No. 6). Center for Research on Information Technology and Organizations, UC Irvine.

Assor, A., Kanat-Maymon, Y., \& Roth, G. (2014). Parental conditional regard: Psychological costs and antecedents. In N. Weinstein (Ed.), Human motivation and interpersonal relationships (pp. 215-237). Netherlands: Springer.

Bass, BM, \& Bass, R. (2008). The Bass handbook of leadership: Theory, research, and managerial applications. Free press.

Banoglu, K. (2011). School principals' technology leadership competency and technology coordinatorship. Educational Sciences-Theory and Practice, 11 (1), 208-213

Billheimer, DM (2007). A study of West Virginia principals: Technology standards, professional development, and effective instructional technology leaders [Doctoral Dissertation, Marshall University Graduate College].http://citeseerx.ist.psu.edu/view doi $=10.1 .1 .886 .4542 \&$ rep $=$ rep1 \& type $=$ pdf

Bush, T. (2011). Theories of educational leadership and management (4th ed.). Sage.

Chin, WW (1998). The partial least squares approach to structural equation modeling. In GA Marcoulides (Ed.), Modern methods for business research (pp. 295-336). Lawrence Erlbaum. 
Chang, IH (2012). The effect of principals 'technological leadership on teachers' technological literacy and teaching effectiveness in Taiwanese elementary schools. Educational Technology \& Society, 15 (2), 328 340 .

Duarte, P., \& Raposo, M. (2010). A PLS model to study brand preference: An application to the mobile phone market. In VE Vinzi, WW Chin, J. Henseler, \& H. Wang (Eds.), Handbook of partial least squares (pp. 449-485). Springer.

Duncan, TG, \& McKeachie, WJ (2005). The making of the motivated strategies for learning questionnaire. Educational Psychologist, 40, 117-128.

Deci, EL, Vallerand, RJ, Pelletier, LG, \& Ryan, RM (1991). Motivation and education: The selfdetermination perspective. Educational Psychologist, 26 (3-4), 325-346.

Eagly, AH (1995). The science and politics of comparing women and men. American Psychologist, 50 (3), 145-158.

Esplin, NL (2017). Utah elementary school principals' preparation as technology leaders.https://digitalcommons.usu.edu/etd/5774

Fornell, C., \& Larcker, DF (1981). Evaluating structural equation models with unobservable variables and measurement errors. Journal of Marketing Research, 18 (1), 39-50.

Gottfried, AE, Marcoulides, GA, Gottfried, AW, Oliver, PH, \& Guerin, GW (2007). Multivariate latent change modeling of developmental decline in academic intrinsic math motivation and achievement: Childhood through adolescence. International Journal of Behavioral Development, 31, 317-327.

Hamzah, MIM, Nordin, N., Jusoff, K., Karim, RA, \& Yusof, Y. (2010). A quantitative analysis of Malaysian secondary school technology leadership. Management Science and Engineering, 4 (2), 124-130.

Hair, JF, Black, WC, Babin, BJ, \& Anderson, RE (2010). Multivariate data analysis (7th ed.). Upper Saddle River, New Jersey: Prentice Hall.

Heafner, T. (2014). Gender differences in technology integration. In M. Searson \& M. Ochoa (Eds.), Proceedings of SITE 2014 - Society for Information Technology \& Teacher Education International Conference (pp. 2841-2851). Association for the Advancement of Computing in Education.https: //www.learn techlib.org/primary/p/131227/

International Society for Technology in Education. (2014). ISTE standards administrators.https://id.iste.org/docs/pdfs/20-14_ISTE_Standards-A_PDF.pdf

Katz, I., Assor, A., \& Kanat-Maymon, Y. (2008). A projective assessment of autonomous motivation in children: Correlational and experimental evidence. Motivation and Emotion, 32, 109-119.

Kurland, H., Peretz, H., \& Hertz-Lazarowitz, R. (2010). Leadership style and organizational learning: The mediate effect of school vision. Journal of Educational Administration, 48 (1), 7-30. http://doi.org/10.1108/09578231011015395

Leithwood, K., \& Jantzi, D. (2006). Transformational school leadership for large-scale reform: Effects on students, teachers, and their classroom practices. School Effectiveness and School Improvement, 17 (2), 201-227.

Leong, MW, Chua, YP, Sathiamoorthy, K., \& Shafinaz, AM (2016). Relationship between ICT teacher competency and teacher acceptance and use of the School Management System (SMS). Malaysian Online Journal of Educational Technology, 4 (4), 30-52.

Martin, AJ (2008). Enhancing student motivation and engagement: The effects of a contemporary multidimensional intervention. Educational Psychology, 33, 239-269. 
Metcalf, WB (2012). K-12 principals' perceptions of their technology leadership preparednesshttps: //digitalcommons.georgia southern.edu/cgi/viewcontent.cgi?article=1400\&context=etd

Nigh, J., Pytash, KE, Ferdig, RE, \& Merchant, W. (2015). Investigating the potential of MOOCs in K-12 teaching and learning environments. Journal of Online Learning Research, 1 (1), 85-106

Northouse, PG (2013). Leadership: Theory and practice (6th ed.), Sage.

Papa, R. (2011). Technology leadership for school improvement. Sage.

Pintrich, PR (2000). The role of orientation in self-regulated learning. In M. Boekaerts, PR Pintrich, \& M. Zeidner (Eds.), Handbook of self-regulation (pp. 451-502). San Diego: Academic Press.

Pintrich, PR (2003). A motivational science perspective on the role of student motivation in learning and teaching contexts. Journal of Educational Psychology, 95 (4), 667-686.

Pintrich, PR (2004). A conceptual framework for assessing motivation and self-regulated learning in college students. Educational Psychology Review, 16, 385-407.

Ryan, RM, \& Deci, EL (2000). Self-determination theory and the facilitation of intrinsic motivation, social development, and well-being. American Psychologist, 55 (1), 68-78.

Riding, RJ, \& Rayner, SG (1998). Cognitive styles and learning strategies: Understanding style differences in learning and behavior. London: David Fulton.

Robbin, SP, \& Judge, TA (2013). Organizational behavior (Vol. 15). Prentice Hall.

Schrum, L., Galizio, LM, \& Ledesma, P. (2011). Educational leadership and technology integration: An investigation into preparation, experiences, and roles. Journal of School Leadership, 21 (2), 241-261.

Schwab, K., \& Davis, N. (2018). Shaping the Fourth Industrial Revolution (1st ed.). Crown Publishing Group.

Waxman, HC, Boriack, AW, Lee, YH, \& MacNeil, A. (2013). Principals' perceptions of the importance of technology in schools. Contemporary Educational Technology, 4 (3), 187-196.

Weinstein, CE, Goetz, ET, \& Alexander, PA (Eds.) (1988). Learning and study strategies: Issues assessment, instruction, and evaluation. San Diego: Academic Press.

Weinstein, CE, Husman, J., \& Dierking, DR (2000). Self-regulation interventions with a focus on learning strategies. In M. Boekaerts, PR Pintrich, \& M. Zeidner (Eds.), Handbook of self-regulation (pp. 727-747). London: Academic Pres

World Economic Forum. (2019). https://www.weforum.org/agenda/2019/01/these-four-leadership-stylesare-key-to-success-in-the-fourth-industrial-evolution/

Wolters, CA (2010). Self-regulated learning and the 21st century competencies. Retrieved May 13, 2015 from http: //www.hewlett.org/uploads/Self_Regulated_Learning__21st_Century_Competencies.pdf.

Yukl, G. (2013). Leadership in organizations (8th ed.). Pearson 